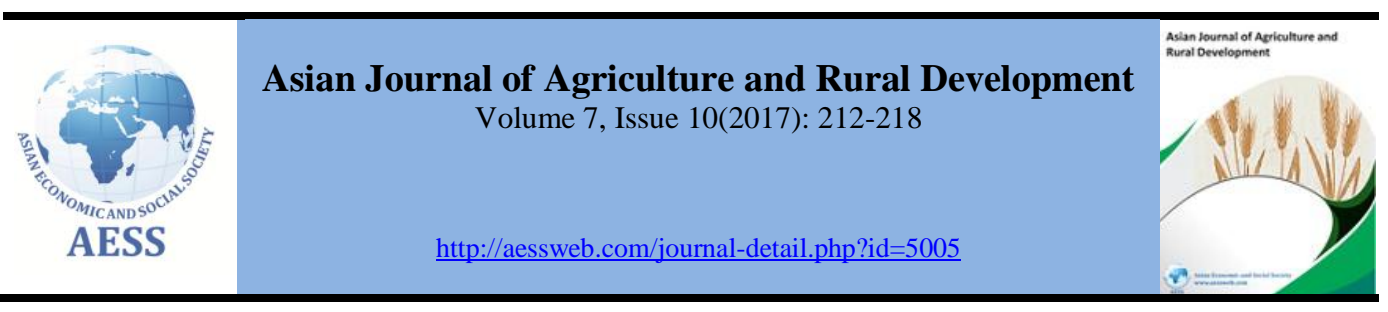

\title{
Impact of Gomal Zam Dam irrigation project on agriculture and welfare of farming community in southern districts of Khyber Pakhtunkhwa-Pakistan
}

\author{
Saad Ali Khan ${ }^{a}$, Syed Attaullah Shah ${ }^{a^{*}}$, Irfan Ullaha, Muhammad Ibrahim ${ }^{\mathrm{b}}$, Salman Khan \\ ${ }^{\text {a }}$ Department of Agricultural \& Applied Economics, University of Agriculture Peshawar, Pakistan \\ ${ }^{\mathrm{b}}$ University of Agriculture AMK Campus Mardan, Pakistan \\ *Email address: syedshah313@gmail.com (Corresponding Author)
}

\section{ARTICLE HISTORY:}

Received: $21-$ Apr-2018

Accepted: 25-May-2018

Online available: 18 -Jun2018

\section{Keywords:}

Gomal Zam Dam (GZD), Canal water irrigation,

Spate irrigation,

Southern districts of

Khyber Pakhtunkhwa,

Pakistan

\begin{abstract}
This study investigated impact of Gomal Zam Dam (GZD) irrigation project on agriculture and welfare of farm households in Southern districts of Khyber Pakhtunkhwa, Pakistan. The study found immense effect of the project on increase in cultivated area and yield of wheat and gram crops, and diversification of traditional cropping pattern to commercialized farming with the addition of sugarcane and vegetables. The availability of irrigation water also induced cultivation of fodder crops which enabled farmers to add large ruminants to their livestock herds. All these changes resulted improvement in farmers' welfare and development in project area. There are various post project needs which are equally important for long term success. The most important of these needs are training of farmers on water use efficiency; provision of technical assistance on using high yielding seed varieties, chemical fertilizers and pesticides; and provision of credit and subsidies for dairy farming.
\end{abstract}

\section{Contribution/ Originality}

This research study was designed to evaluate the impact of Gomal Zam Dam (GZD) Irrigation project on farm level agriculture in D. I. Khan and Tank districts in Southern KP province. Findings from this study support government investment in hydropower and irrigation infrastructure development in the Southern districts of KP province. Such investment will be more effective in improving farming community's welfare and growth in the agricultural sector of the province.

DOI: 10.18488/journal.1005/2017.7.10/1005.10.212.218

ISSN (P): 2304-1455/ISSN (E):2224-4433

Citation: Saad Ali Khan, Syed Attaullah Shah, Irfan Ullah, Muhammad Ibrahim and Salman Khan (2017). Impact of Gomal Zam Dam irrigation project on agriculture and welfare of farming community in southern districts of Khyber Pakhtunkhwa-Pakistan. Asian Journal of Agriculture and Rural Development, 7(10), 212-218.

(C) 2017 Asian Economic and Social Society. All rights reserved. 


\section{INTRODUCTION}

Agriculture, which is the back bone of the Pakistan's economy, has a declining share in the Gross Domestic Production for the past years. This decline in agricultural share is a result of growth in the industrial and services sectors of the economy. However, agricultural production for major crops are showing upward trends. Increase in production of major crops, such as Rice, Cotton, Wheat and Sugarcane, are key for growth in agro-based industries. Also, agriculture is a main source of employment, and it feeds the whole rural and urban population of the country (GoP, 2017). That's why government policy makers are always committed to work for growth in this sector and to solve its major problems.

Increase in production of major crops can be achieved through intensive and extensive practices. Intensive agriculture is the use of high yielding seed varieties and recommended fertilizers doses of fertilizers and chemicals for increasing crops yield. Extensive agriculture means expansion in cultivated area under major crops, and this can be achieved through provision of irrigation facility in rain-fed areas. Construction of small, medium and large dams and water canals for irrigation can help in utilizing uncultivated land for crops production (Khan and Shah, 2012; Khan et al., 2011; Majeed et al., 2010; Sarwar and Bastiaanssen, 2001).

The Southern districts of Khyber Pakhtunkhwa have potential for extensive crops production; however, due to unavailability of irrigation water, agricultural productivity is low and most of the area is barren. After the construction of Chashma Right Bank Canal, water requirement has been fulfilled on substantial agricultural land of D. I. Khan. The availability of water has resulted diversification in cropping pattern and increase in yield of major crops. The government of Khyber Pakhtunkhwa is now executing another water resources development project- the Gomal Zam Dam (GZD) project. The gross command area of the project is 271,038 acres comprising of 192166.46 acres in Tank, 110,957 acres in Kulachi and 27,929 acres in D. I. Khan.

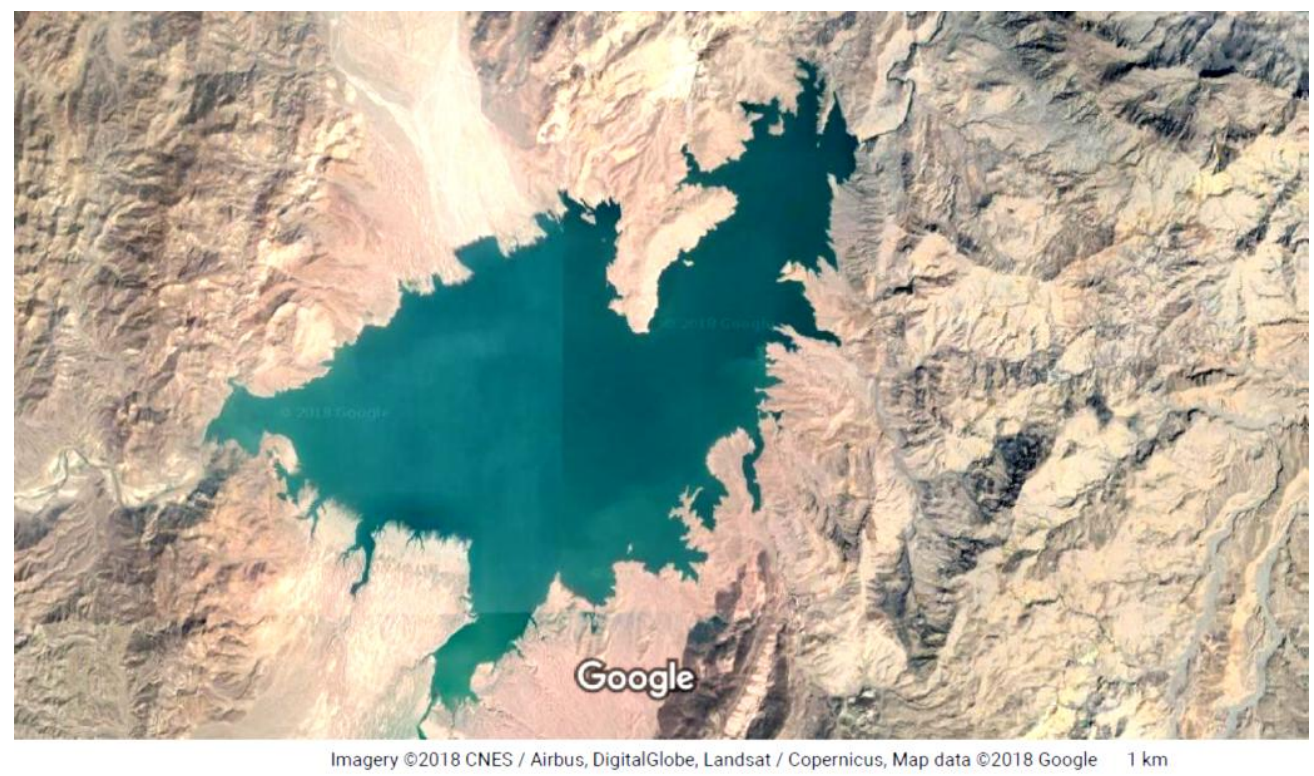

Figure 1: Ariel view of Gomal Zam dam

The GZD command area is well known for spate irrigation, locally named as Rod Kohi, and is practiced for centuries in this area (Asif et al., 2016; Nawaz and Han, 2006). During monsoon period, water is stored and is used for irrigating crops in winter season (Ahmad and Choudhry, 2005). The climate of the project area is hot in summer and moderately cold in winter, and mean annual 
precipitation is around 250-270 $\mathrm{mm}$. Current cropping pattern include Wheat (Triticum aestivum) and Gram (Ciccer aeritinum) as major crops. Huge potential exists for production of cereals and cash crops if provided with irrigation water.

This study investigated the impact of the GZD irrigation system on agricultural productivity, area allocation to major crops, dairy farming and farmers' welfare.

\section{MATERIALS AND METHODS}

\subsection{Sampling and data collection}

A two stage stratified sampling technique was used to select a sample of beneficiaries and nonbeneficiaries from the study area. In the first stage, four villages were purposively selected from GZD command area-two located in D.I. Khan District (beneficiaries) and two in Tank district (nonbeneficiaries). In the second stage, 25 farmers were selected randomly from each village. Thus a sample of 100 farmers was selected having equal number of beneficiaries and non-beneficiaries of GZD irrigation project.

Data were collected from the selected farm households and for this purpose a well-designed and pretested questionnaire was used. Other required information were collected from different secondary sources, such as published reports of different government departments.

\subsection{Analytical framework}

To evaluate the impact of GZD irrigation project on on-farm area allocation to major crops (wheat and gram) and their yields per acre, independent sample t-tests were conducted.

$$
t=\frac{\left(\bar{X}_{1}-\bar{X}_{2}\right)}{\sqrt{\frac{s_{1}^{2}}{n_{1}}+\frac{s_{2}^{2}}{n_{2}}}}
$$

Where;

$(1,2)$ represent beneficiaries and non-beneficiaries of GZD irrigation project

$t$ is the ' $t$-statistic'

$n_{1}$ and $n_{2}$ are the number of beneficiaries and non-beneficiaries, respectively;

$\bar{X}_{1}$ and $\bar{X}_{2}$ are the corresponding mean value for their respective cultivated area or yield

$S_{1}^{2}$ and $S_{2}^{2}$ are the respective unbiased estimator of the variances for beneficiaries and nonbeneficiaries.

The associations of cultivation of cash crops, such as sugarcane and vegetables, and rearing of cows and buffaloes with availability for irrigation water from GZD project were checked through Pearson $\chi^{2}$ test.

$$
x^{2}=\sum \frac{\left(O_{i}-E_{i}\right)^{2}}{E_{i}}
$$

Where:

$\chi^{2}$ represents Chi-Square Distribution

$O$ is the observed value

E represents expected value

Household's aggregate monthly expenditure (food and non-food) was used as a welfare indicator in the following dummy variable regression model to estimate the effect of GZD-irrigation project on their wellbeing.

$$
C E_{j}=\beta_{0}+\beta_{1} D_{j}
$$


Where:

$C E_{j}$ is total monthly expenditure of the $j^{\text {th }}$ farm household.

$D$ is a dummy variable, 1 if $j^{\text {th }}$ farm household is beneficiary of GZD-irrigation project, otherwise 0 .

$\beta_{0}$ is the intercept or the $j^{\text {th }}$ farm household's average monthly expenditure.

$\beta_{1}$ is coefficient of dummy variable $D$, representing change in farm household's monthly expenditure because of GZD irrigation project.

\section{RESULTS AND DISCUSSION}

This section is divided into two parts. The first part present characteristics of the interviewed farm households and the second part report results on the impacts of the GZD irrigation project on area allocation to major crops, yields, cropping pattern, dairy farming and monthly expenditure of the farm households in the command area.

\subsection{Characteristics of the farm households}

The GZD command area comprises an approximate population of about $355,000(252,000$ in D.I.Khan and 103,000 in Tank). The clans residing in the area are Unnara, Kannera, Baloch, Gandapure, Manjhikhel, Khokhar and Masud. The languages spoken widely are Saraiki and Pashto.

Data collected from interviewed farm households show that male and female proportion in the command area was 51\% and 49\%, respectively; average household size was 11 individuals; and most of them were headed by male member. Literacy rate was low because of non-functional schools and unqualified staff. Around $75 \%$ of the community members were illiterate and were unable to read and write, while only $25 \%$ were literate. Female members were more illiterate $(83.5 \%)$ as compared to male members ( $68 \%$ illiterate), this was due to the unavailability of middle and higher schools for female in the area. Agriculture was the main source of their income, and their average farm size was 50 acres. Around $50 \%$ of the interviewed farm households were owner of their farm land, $40 \%$ were tenant and $10 \%$ were owner-cum-tenants.

\subsection{Impacts of GZD irrigation project on}

\subsubsection{Cultivated land}

The availability of perennial source of water for irrigation has increased the area under crops and is a game changer for the people using traditional flood management system for the production of crops. Descriptive statistics for farm size and on-farm cultivated land are given in Table 1. Average farm size of the non-beneficiaries was 60.7 acres and average cultivated land was 19.0 acres. The cultivated land was around $30.9 \%$ of their total farm size. The beneficiaries' farm size was 40.1 acres, out of which cultivated land was 28.1 acres $(66.7 \%)$. It clearly shows that beneficiary farmers were practicing extensive agriculture on their farm. GZD irrigation project helped them in utilizing barren land for cultivation of crops.

Table 1: Average farm size and cultivated land

\begin{tabular}{lcc}
\hline Farmers & $\begin{array}{c}\text { Average Farm Size } \\
\text { (Acres) }\end{array}$ & $\begin{array}{c}\text { Cultivated Land } \\
\text { (Acres) }\end{array}$ \\
\hline Non-Beneficiary & 60.7 & $19.0(30.9 \%)$ \\
Beneficiary & 40.1 & $28.1(66.7 \%)$ \\
Total & 50.4 & $24.1(48.3 \%)$ \\
\hline
\end{tabular}

Source: Survey data (2016) 


\subsubsection{Major crops cultivation}

Wheat is the staple food cultivated for the last 5 decades in the area through traditional Rod Kohi farming practice and its by-products is utilized as fodder for livestock. Wheat cultivated area were 10.5 acres and 16.8 acres on non-beneficiary and beneficiary farms, respectively (Table 2). This high cultivated area for wheat crop on a beneficiary's farm was apparently because of the water availability from GZD-irrigation system. Gram, the second most important food crop after wheat, was cultivated on 4.0 acres and 7.4 acres of a non-beneficiary and a beneficiary farm, respectively (Table 2). Again, this significant difference of 3.4 acres on a beneficiary farm was resulted because of the GZD-irrigation project.

Table 2: Land allocation for major crops

\begin{tabular}{lccc}
\hline \multirow{2}{*}{ Crops } & \multicolumn{2}{c}{ Land Allocation } & T-test statistic $(\mathbf{P}-$ \\
value $)$
\end{tabular}

Source: Survey data (2016)

\subsubsection{Major crops' yields}

Before, GZD Project, the timely availability of water for irrigation was a major problem. Now, the availability of perennial flow of water for irrigation has enhanced the agricultural productivity for major crops.

Table 3 shows that average yield of wheat on non-beneficiary and a beneficiary farms were $700 \mathrm{Kgs}$ and $1230 \mathrm{Kgs}$ per acre, respectively. This high yield on beneficiary farm was because of water availability from GZD - Irrigation project and this increase in yield (by 530Kgs) is statistically significant, as indicated by t-statistic value of 5.01 and associated P-value of $<0.001$. The same table shows that average yield of gram on a non-beneficiary and a beneficiary farms were on average 334 $\mathrm{Kgs}$ and $713 \mathrm{Kgs}$ per acre. The estimated t-statistic value of 6.40 is statistically significant for increased yield on beneficiary farm due to water availability from GZD - Irrigation system.

\section{Table 3: Yields for major crops}

\begin{tabular}{|c|c|c|c|}
\hline \multirow{2}{*}{ Crops } & \multicolumn{2}{|c|}{ Yield per Acre } & \multirow{2}{*}{$\begin{array}{c}\text { T-test statistic (P- } \\
\text { value) }\end{array}$} \\
\hline & Non-Beneficiaries & Beneficiaries & \\
\hline Wheat & $700 \mathrm{Kgs}$ & $1230 \mathrm{Kgs}$ & $5.01(<0.001)$ \\
\hline Gram & $334 \mathrm{Kgs}$ & $713 \mathrm{Kgs}$ & $6.40(<0.001)$ \\
\hline
\end{tabular}

Source: Survey data (2016)

\subsubsection{Cultivation of cash crops}

Farmers having irrigation facility are likely to diversify their cropping pattern. The beneficiaries of GZD-irrigation system have started cultivating cash crops (sugarcane and vegetables). The given table 4 presents that $56 \%$ of the beneficiaries had started cultivating sugarcane, while the nonbeneficiaries were unable to cultivate it. Similarly $74 \%$ of the beneficiary farmers were cultivating vegetables, while only $28 \%$ of the non-beneficiary farmers were able to cultivate them. The estimated Pearson chi-square statistics and associated p-values reveal significant association of cultivation of sugarcane and vegetables with water availability from GZD-irrigation system.

Increase in cultivation of sugarcane and vegetables could significantly increase farmers' income from agriculture. 
Table 4: Sugarcane and vegetables cultivation in the GZD command area

\begin{tabular}{lcccc}
\hline \multirow{2}{*}{ Farmers } & \multicolumn{2}{c}{ Sugarcane } & \multicolumn{2}{c}{ Vegetables } \\
& No & Yes & No & Yes \\
\hline Non-Beneficiaries & $50(100 \%)$ & $0(0 \%)$ & $36(72 \%)$ & $14(28 \%)$ \\
Beneficiaries & $22(44 \%)$ & $28(56 \%)$ & $13(26 \%)$ & $37(74 \%)$ \\
All & $62(62 \%)$ & $28(28 \%)$ & $49(41 \%)$ & $51(51 \%)$ \\
Pearson chi2 & \multicolumn{2}{c}{$45.488(0.000)$} & 18.082 & $(0.000)$ \\
(P-value) & \multicolumn{2}{c}{} \\
\hline
\end{tabular}

Source: Survey data (2016)

\subsubsection{Livestock farming}

Irrigation facility in different ways can have a positive effect on livestock farming. Irrigated farming increase potential for green fodders production and motivate farmers to increase the number of large ruminants, such as cows and buffaloes, in their livestock herd. Increase in the number of these animals increase milk production and enhances farm household's income. Table 5 shows that $73 \%$ of the interviewed beneficiaries were rearing buffaloes and cows for milk production. On the nonbeneficiaries side only $27 \%$ of the interviewed farmers were rearing cows and buffaloes for milk production. The estimated Pearson chi-square value reveals significant association between irrigation facility and rearing of milk producing animals.

\section{Table 5: Impact of GZD irrigation project on adoption of milking animals}

\begin{tabular}{lcc}
\hline \multirow{2}{*}{ Farmer } & \multicolumn{2}{c}{ Cows and Buffaloes } \\
& No & Yes \\
\hline Non-Beneficiaries & $36(73 \%)$ & $14(27 \%)$ \\
Beneficiaries & $15(28 \%)$ & $35(72 \%)$ \\
Total & $41(100 \%)$ & $59(59 \%)$ \\
\hline
\end{tabular}

Pearson chi2 $(1)=10.482 \quad \operatorname{Pr}=0.001$

\subsubsection{Household's welfare}

The GZD-irrigation system, through ensuring timely availability of water for production of crops, has sustained agricultural returns and has improved farm household's returns.

Welfare economists use household's expenditures on food and non-food items as an indicator of their welfare status. That is why this study used farm household's expenditure as a proxy for measuring improvement in their welfare.

The estimated results for the dummy variable regression reveals that farm household's monthly expenditure was on average 25918 rupees, and the expenditure for a beneficiary farm household was greater than the non-beneficiary's by 18706 rupees. As indicated by T-statistics value of 3.52 and $\mathrm{P}$-value of 0.001 , this increase in the expenditures is statistically significant.

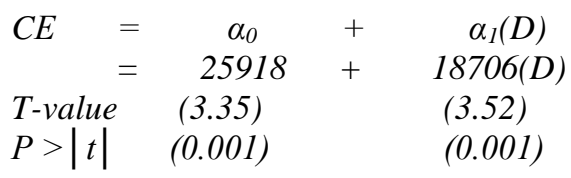

\section{CONCLUSIONS AND RECOMMENDATIONS}

The GZD-irrigation system has resulted increase in land allocation and yield for wheat and gram crops. The farm households have started growing high value crops, such as sugarcane and 
vegetables, and rearing of cows and buffaloes. This crops-livestock mixed agricultural strategy has increased and secured income. All these changes reveal that GZD-irrigation system has an immense effect on farm households' welfare in the area.

Findings of this study favor government investment in hydropower and irrigation infrastructure development in the Southern districts of KP. Such investment will be more effective in improving farming community's welfare and growth in the agriculture sector of the province.

There are various post project needs which are equally important for the success of the GZDirrigation project and achieving its long term goals. The most important of these needs are training of farmers on modern agricultural farming for water use efficiency; provision of technical assistance on use of high yielding seed varieties, chemical fertilizers and pesticides; and provision of credit and subsidies for dairy farming.

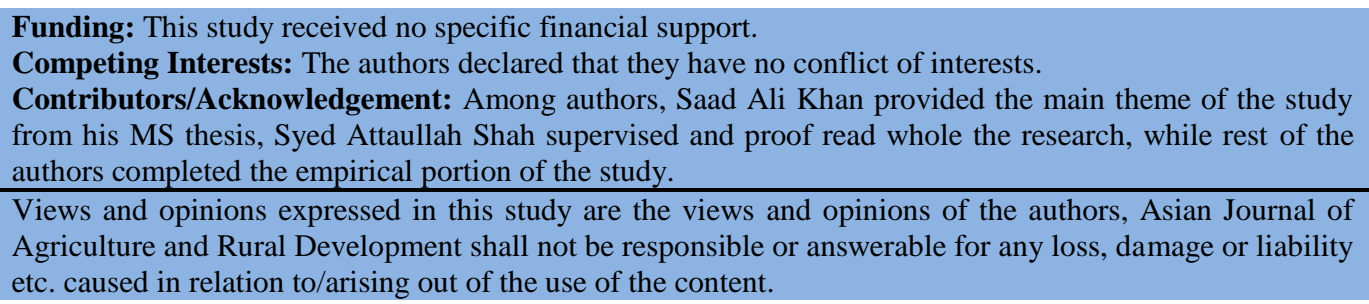

\section{References}

Ahmad, M., \& Choudhry, M. R. (2005). Farmers' irrigation practices under Rod Kohi irrigation system. Pakistan Journal of Water Resources, 9(1), 25-33. view at Google scholar

Asif, M., Akbar, G., Ahmad, M. M., \& Khattak, M. S. (2016). Impact of Rod Kohis improvement on water conveyance losses and wheat yield. Journal of Himalayan Earth Sciences Volume, 49(1), 110-116. view at Google scholar

GoP (2017). Pakistan economic survey. Pakistan Buru of Statistics, Islamabad. view at Google scholar

Khan, H., \& Shah, M. (2012). Irrigation, farm productivity and poverty reduction in kpk: understanding direct and indirect impacts and linkages. Procedia Economics and Finance, 2, 292-298. view at Google scholar / view at publisher

Khan, M. T., Islam, M., Chattha, T. H., \& Hayat, R. (2011). Impacts of mini dams on socioeconomic development of farmers of rainfed region. J. Agric. Soc. Sci, 7(4), 124-130. view at Google scholar

Majeed, S., Ali, I., Zaman, S. M., \& Ahmad, S. (2010). Productivity of mini dams in pothwar plateau: a diagnostic analysis. Research briefings. Natural Resource Division, Pakistan Agricultural Research Council, Islamabad, 2(13), 1-19. view at Google scholar

Nawaz, M., \& Han, M. (2006). Hill torrents management for increasing agricultural activity in Pakistan. Department of Civil and Environmental Engineering, Seoul National University Korea. E-mail: daring511@ hotmail.com. view at Google scholar / view at publisher

Sarwar, A., \& Bastiaanssen, W. G. (2001). Long-term effects of irrigation water conservation on crop production and environment in semiarid areas. Journal of Irrigation and Drainage Engineering, 127(6), 331-338. view at Google scholar / view at publisher 